\title{
An Analysis of Coaches' Unethical Behaviors in terms of Sociodemographic Variables
}

\author{
Levent Tanyeri ${ }^{1, *}$ \\ ${ }^{1}$ School of Sarıkamış Physical Education and Sport, Kafkas University, Kars, Turkey \\ *Correspondence: School of Sarıkamış Physical Education and Sport, Kafkas University, Kars, Turkey. E-mail: \\ ireynat10@hotmail.com
}

Received: July 24, 2019

Accepted: August 22, 2019 Online Published: August 25, 2019

doi:10.5430/wje.v9n4p103

URL: https://doi.org/10.5430/wje.v9n4p103

\begin{abstract}
In addition to physical struggle, sports are also closely related to moral behaviors and attitudes. The will to succeed and win which plays a central role in sports also brings about various ethical questions. In this respect, the present study aims to analyze coaches' unethical behaviors in terms of socio-demographic variables. To this aim, a total of 173 students comprised of 100 male students and 73 female students were invited to participate in the present study. "Athlete Perception Scale about Coaches' Unethical Behaviors" developed by Güven and Öncü (2012) and a "personal information form" developed by the researcher was used data collection tools in the present study, and the findings indicate a normal data distribution. No significant differences were found among scale scores in terms of gender, sports branch and level of sportsmanship. However, it was also demonstrated that years of athletic experience had a significant effect on students' views on coaches' unethical behaviors.
\end{abstract}

Keywords: trainer, unethical behavior, sociodemographic

\section{Introduction}

During a time period when moral values are slowly being replaced by material values, it is becoming more and more difficult for people to encounter ethically and morally right behaviors in their individual and social relationships. Nevertheless, when performing their jobs, an individual in a certain professional group is often expected to behave justly, value people, show them respect and love, and display these behaviors explicitly (Dolaşır-Tuncel \& Büyüköztürk, 2009). Competence is a given professional field is not only measured by relevant knowledge and skills in that field but also being familiar with right attitudes and behaviors in that field (William, Davis, \& Post, 1988), which is also valid for coaches as one of the most indispensable elements in the world of sports. There is no doubt that a coach's duty is not limited to training athletes or showing them how certain athletic skills are performed. A coach should interpret information given by sports scientists, physicians and psychologists and compare them with their own knowledge before introducing it to their athletes (Fain, 1992), which draws attention to the concept of ethics in sports.

The word "ethics" is derived from the Greek word "ethos". In addition, it also means "habit, tradition" in Greek, and points to behaviors conforming to "moral code" in a society (Şimşek \& Altınkurt, 2009). Ethics can be defined as a set of values and moral principles which determine criteria for distinguishing between the good and bad, reason and produce information about morality, set certain principles and standards for individuals and groups, and guide an individual's or groups' behaviors about what is right and what is wrong (Cevizci, 2002). Several studies were found in the existing literature on the relationship between ethics, personality structure and physical education teachers (Togo, 2016; Janelle \& Taylor, 1994; Kıranlı, 2002; Özbek, 2003; Öncen \& Aydın, 2019). Gürpınar analyzed basketball and football referees' views on coaches' unethical behaviors and reported that unethical behaviors were mostly displayed by spectators, while technical staff including coaches displayed the least number of unethical behaviors (Gürpınar, 2009). Dolaşır-Tuncel and Büyüköztürk (2009) measured the level of athletes' and coaches' professional ethical behaviors in a national team camp thanks to their professional ethics scale for coaches. Güven and Öncü (2012) developed a scale in order to determine athletes' perception on coaches' unethical behaviors. When the literature is examined, it is seen that some researchers have done similar studies (Çeviker, 2013; Genç et al., 2013; 
Karakoç et al., 2011; Yaman et al., 2009).

The notion of ethics raises the question of winning and losing or success in a sports branch, and bears a moral dimension for individuals who are engaged in or benefit sports activities. The importance of moral values in a sports environment where athletes commit to ethical principles is undeniable. The existence of ethical principles in a sports environment will greatly contribute to the commitment of shareholders such as athletes, coaches, managers and spectators to sports activities. In this respect, the present study analyzes coaches' unethical behaviors in terms of socio-demographic variables, and focuses on the following research questions: (1) What are athletes' perceptions of coaches' unethical behaviors? (2) Does gender as a variable significantly affect athletes' perceptions of unethical behaviors? (3) Does years of athletic experience as a variable significantly affect athletes' perceptions of unethical behaviors? (4) Does sports branch as a variable significantly affect athletes' perceptions of unethical behaviors? (5) Does level of sportsmanship as a variable significantly affect athletes' perceptions of unethical behaviors? (6) Does training with a professional coach as a variable significantly affect athletes' perceptions of unethical behaviors?

\section{Method}

\subsection{Research Group}

A total of 173 university students comprised of 100 male students and 73 female students participated in the present study in order to evaluate coaches' unethical behaviors. These students have participated in sports activities in different sports branches (football, basketball, volleyball, and handball) for different durations.

\subsection{Data Collection Tools}

In the present study, “Athlete Perception Scale about Coaches' Unethical Behaviors” developed by Güven and Öncü (2012) and a "personal information form" developed by the researcher were used as data collection tools.

Athlete Perception Scale about Coaches' Unethical Behaviors: This 5-point Likert type scale was designed to measure coaches' unethical behaviors in athletes' perceptions. The statements are listed as "Strongly Agree", "Agree", "Neutral", "Disagree", "Strongly Disagree" and scored as "5, 4, 3, 2 and 1" (Güven and Öncü, 2012). Personal information form consists of questions related to gender, years of athletic experience, sports branch, level of sportsmanship and training with a professional coach.

\subsection{Data Collection}

The present study focused on students' views on coaches' unethical behaviors. For this purpose, a data collection tool was designed, and an online questionnaire form was sent to the students for data collection process. The survey was conducted on a voluntary basis, and the data were collected in parallel with this principle. 173 different data collected from students' responses were transferred to a computer for further analysis.

\subsection{Data Analysis}

A normality test was applied to the data obtained from students' responses. Skewness and kurtosis tests demonstrated that the data displayed a normal distribution. In this respect, descriptive values were presented, and $t$ test and one-way analysis of variance ANOVA test were performed. Tukey test, a multiple comparison test, was used in order to determine significant differences among certain groups in ANOVA test. The level of significance was taken as $\mathrm{p}<0.05$ in the analysis.

\section{Findings}

Table 1. Scale Score Distribution

\begin{tabular}{lccccccc}
\hline \multicolumn{1}{c}{ Scale sub-dimensions } & N & Min. & Max. & Mean & Ss. & Skewness & Kurtosis \\
\hline Coach-Athlete Relationship & 173 & 10.00 & 50.00 & 2.13 & 10.10 & .780 & .008 \\
Sportsmanship & 173 & 5.00 & 25.00 & 1.88 & 5.26 & 1.133 & .404 \\
Personal Traits & 173 & 4.00 & 20.00 & 1.92 & 4.51 & .923 & -.311 \\
Total Score & 173 & 19.00 & 95.00 & 2.02 & 1.35 & .870 & .077 \\
\hline
\end{tabular}

Descriptive values of the obtained data are presented in Table 1. It can be understood that skewness and kurtosis values of the data obtained from students' responses display a normal distribution. In addition, it can also be observed in the scale that participants generally had a low level of perception of coaches' levels of unethical behaviors. 
Table 2. The Analysis of Coaches' Unethical Behaviors in Terms of Gender

\begin{tabular}{ccccccc}
\hline Scale sub-dimensions & Gender & N & Mean & Ss & t & p \\
\hline Coach-Athlete Relationship & Male & 100 & 22.57 & 10.67 & 1.841 & .067 \\
& Female & 73 & 19.72 & 9.08 & & \\
Sportsmanship & Male & 100 & 9.76 & 5.74 & .955 & .341 \\
& Female & 73 & 9.01 & 4.52 & & \\
Personal Traits & Male & 100 & 7.95 & 4.79 & .794 & .428 \\
& Female & 73 & 7.39 & 4.11 & & \\
Total Score & Male & 100 & 40.28 & 19.37 & 1.471 & .143 \\
& Female & 73 & 36.13 & 16.68 & & \\
\hline
\end{tabular}

Table 2 indicates findings related to the significant effect of gender as a variable on the perception of coaches' unethical behaviors. No significant differences were observed between male and female students' perception of coaches' unethical behaviors in the scale and its sub-dimensions $(\mathrm{p}>0.05)$.

Table 3. The Relationship between Students' Years of Athletic Experience and Coaches' Unethical Behaviors

\begin{tabular}{|c|c|c|c|c|c|c|c|}
\hline $\begin{array}{c}\text { Scale } \\
\text { sub-dimensions }\end{array}$ & $\begin{array}{c}\text { Years of } \\
\text { athletic } \\
\text { experience }\end{array}$ & $\mathbf{N}$ & Mean & Ss. & $\mathbf{F}$ & $\mathbf{p}$ & Significant groups \\
\hline \multirow{3}{*}{$\begin{array}{l}\text { Coach-Athlete } \\
\text { Relationship }\end{array}$} & $0-2$ years & 35 & 24.57 & 11.78 & \multirow{3}{*}{2.321} & \multirow{3}{*}{.101} & \multirow{6}{*}{$\begin{array}{c}0-2 \text { years }>6 \text { years } \\
\text { and over }\end{array}$} \\
\hline & $3-5$ years & 49 & 20.08 & 7.97 & & & \\
\hline & $\begin{array}{c}6 \text { years and } \\
\text { over }\end{array}$ & 89 & 20.82 & 10.29 & & & \\
\hline \multirow{3}{*}{ Sportsmanship } & $0-2$ years & 35 & 11.54 & 5.43 & \multirow{3}{*}{3.821} & \multirow{3}{*}{.024} & \\
\hline & $3-5$ years & 49 & 9.30 & 5.30 & & & \\
\hline & $\begin{array}{c}6 \text { years and } \\
\text { over }\end{array}$ & 89 & 8.69 & 5.00 & & & \\
\hline \multirow{3}{*}{ Personal Traits } & $0-2$ years & 35 & 9.57 & 4.76 & & & \multirow{3}{*}{$\begin{array}{c}0-2 \text { years }>6 \text { years } \\
\text { and over }\end{array}$} \\
\hline & $3-5$ years & 49 & 7.51 & 4.60 & 3.963 & .021 & \\
\hline & $\begin{array}{c}6 \text { years and } \\
\text { over }\end{array}$ & 89 & 7.10 & 4.21 & & & \\
\hline \multirow{3}{*}{ Total Score } & $0-2$ years & 35 & 45.68 & 20.89 & & & \multirow{3}{*}{$\begin{array}{c}0-2 \text { years }>6 \text { years } \\
\text { and over }\end{array}$} \\
\hline & $3-5$ years & 49 & 36.89 & 16.03 & 3.431 & .035 & \\
\hline & $\begin{array}{c}6 \text { years and } \\
\text { over }\end{array}$ & 89 & 36.61 & 17.99 & & & \\
\hline
\end{tabular}

$\mathrm{p}<0,05$

It can be understood from Table 3 that there were significant differences between students' years of athletic experience and coaches' unethical behaviors. Significant differences can be observed in the scale and in the sub-dimensions of sportsmanship and personal traits. Tukey test demonstrated that this significant difference was in favor of students who had 0-2 years of athletic experience. On the other hand, no significant differences were observed in the sub-dimension of coach-athlete relationship. 
Table 4. Anova Test Results Related to the Effect of Sports Branch on Coaches' Unethical Behaviors

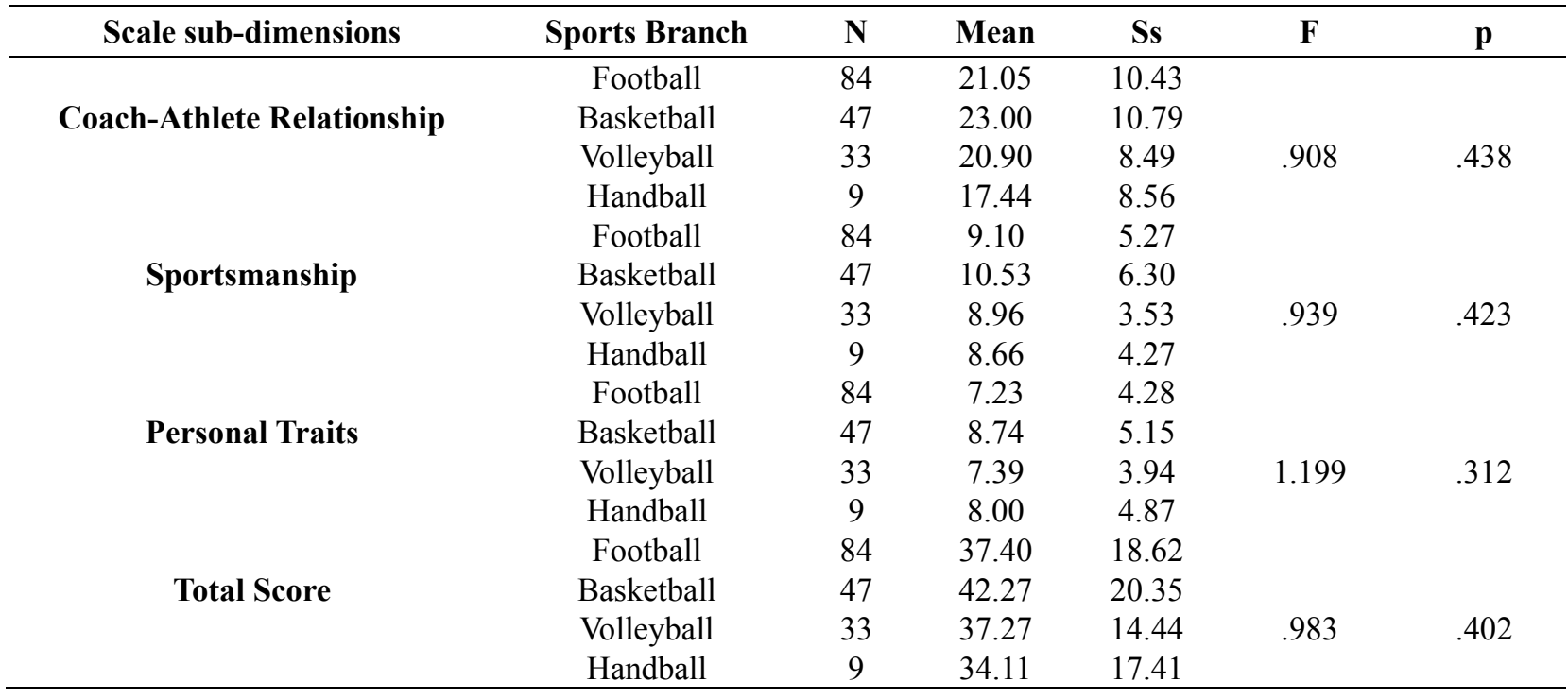

Table 4 indicates whether there were any significant differences between students' sports branch and coaches' unethical behaviors. No significant differences were observed in the scale and its sub-dimensions. Therefore, it can be stated that sports branch did not have any significant effect on the students' perceptions of coaches' unethical behaviors.

Table 5. T Test Results Related to the Effect of Level of Sportsmanship on Coaches' Unethical Behaviors

\begin{tabular}{|c|c|c|c|c|c|c|}
\hline Scale sub-dimensions & $\begin{array}{c}\text { Level of } \\
\text { Sportsmanship }\end{array}$ & $\mathbf{N}$ & Mean & Ss & $\mathbf{t}$ & $\mathbf{p}$ \\
\hline \multirow[t]{2}{*}{ Coach-Athlete Relationship } & Amateur & 156 & 21.44 & 10.02 & .285 & .776 \\
\hline & Professional & 17 & 20.70 & 11.08 & & \\
\hline \multirow[t]{2}{*}{ Sportsmanship } & Amateur & 156 & 9.53 & 5.26 & .706 & .481 \\
\hline & Professional & 17 & 8.58 & 5.29 & & \\
\hline \multirow[t]{2}{*}{ Personal Traits } & Amateur & 156 & 7.83 & 4.48 & 1.029 & .305 \\
\hline & Professional & 17 & 6.64 & 4.75 & & \\
\hline \multirow[t]{2}{*}{ Total Score } & Amateur & 156 & 38.81 & 18.21 & .612 & .542 \\
\hline & Professional & 17 & 35.94 & 19.97 & & \\
\hline
\end{tabular}

Table 5 presents findings related to the significant differences between students who were amateur and professional athletes. It is evident that the level of sportsmanship did not have any significant effect on the students' perception of coaches' unethical behaviors ( $\mathrm{p}>0.05)$.

Table 6. T Test Results Related to the Effect of Level of Training with a Professional Coach on Coaches' Unethical Behaviors

\begin{tabular}{ccccccc}
\hline Scale sub-dimensions & $\begin{array}{c}\text { Have you ever } \\
\text { trained with a } \\
\text { professional coach? }\end{array}$ & N & Mean & Ss & t & p \\
\hline Coach-Athlete Relationship & Yes & 78 & 20.48 & 11.00 & -1.041 & .299 \\
Sportsmanship & No & 95 & 22.09 & 9.30 & -2.013 & $\mathbf{. 0 4 6}$ \\
Personal Traits & Yes & 78 & 8.56 & 5.26 & .129 \\
Total Score & No & 95 & 10.16 & 5.17 & & .125 \\
& Yes & 78 & 7.14 & 4.44 & -1.525 & .129 \\
\hline
\end{tabular}

$\mathrm{p}<0,05$ 
Table 6 indicates whether training with a professional coach had a significant effect on students' perception of coaches' unethical behaviors. It can observed that there was a significant difference in the sub-dimension of sportsmanship $(\mathrm{p}<0.05)$.

\section{Discussion}

It was demonstrated in the present study that the data obtained from the students displayed a normal distribution. It can inferred from mean scale scores that students had a low level of perception when it comes to their own coaches' unethical behaviors, which overlaps the findings in some studies in the literature. For instance, Caz (2019) reported that the data displayed a normal distribution as far as athlete perceptions about coaches' unethical behaviors scale scores are concerned. Similarly, Güvendi et al. (2016) indicated that research data displayed a normal distribution.

It was found out in the present study that there were significant differences between male and female students' perceptions of coaches' unethical behaviors and that this significant difference was in favor of male students. However, Güven and Öncü (2012) did not report any significant differences between males and females. In a similar vein, Certel et al. (2018) did not find out any significant differences between males and females. Dolaşır-Tuncel and Büyüköztürk (2009) reported that male coaches had a higher level of complying with ethical principles compared to female coaches. However, Caz (2019) found no significant differences between male and female athletes' perceptions of coaches' unethical behaviors. These findings do not overlap the present study.

When the scale and sub-dimension scores are analyzed, it can be observed that students' sports branch did not cause any significant differences for coaches' unethical behaviors. Thus, it is evident that sports branch as a variable did not have any significant effect on the students' perceptions of coaches' unethical behaviors. Dolaşır-Tuncel and Büyüköztürk (2009) stated that $1.3 \%$ of the participants were engaged in gymnastics, $4.7 \%$ of them were engaged in body building, $16.0 \%$ of them were engaged in swimming, $8.0 \%$ of them were engaged in tennis, $4.0 \%$ of them were engaged in boxing, $8.0 \%$ were engaged in Taekwon-Do, $19.0 \%$ of them were engaged in basketball, $27.0 \%$ of them were engaged in volleyball, and $12.0 \%$ of them were engaged in handball.

\section{Conclusion}

The data obtained from the students participating in the present study displayed a normal distribution. Mean scale scores demonstrated that coaches had a low level of unethical behaviors. It was also observed that there were significant differences between male and female students' perceptions of coaches' unethical behaviors and that this significant difference was in favor of male students.

Another finding of the present study is that a significant difference was found between students' years of athletic experience and coaches' unethical behaviors. This significant difference was particularly observed in the scale and in the sub-dimensions of sportsmanship and personal traits, indicating that years of athletic experience had a significant effect on coaches' unethical behavior.

When the scale and its sub-dimension scores are analyzed, it can be understood that sports branch as a variable did not cause any significant differences in students' perceptions of unethical behaviors. Another finding is related to the fact that no significant differences were observed between amateur and professional athletes. Therefore, it can be concluded that being an amateur or professional athlete did not have any significant effect on the perception of coaches' unethical behaviors.

\section{Limitations of the Study and Suggestions}

- The study was conducted only with university students.

- Single scale was used in the study.

- Quantitative analysis was used in the study.

- More than one scale can be used in studies.

- The number of participants can be increased.

- Mixed studies can be done using quantitative and qualitative methods. 


\section{References}

Caz, Ç. (2019). Antrenörlerin sergilemiş olduğu etik dışı davranışların sporcu gözüyle değerlendirilmesi. Gelecek Vizyonlar Dergisi, 3(1), 20-25. https://doi.org/10.29345/futvis.65

Certel, Z., Alkış, A., \& Gürpınar, B. (2018). Antrenörlerin mesleki etik ilkelere uyma düzeylerinin antrenör ve sporcu gözüyle değerlendirilmesi. Akdeniz Insani Bilimler Dergisi, 8(2), $223-231$. https://doi.org/10.13114/MJH.2018.418

Cevizci, A. (2002). Etiğ Giriş. İstanbul: Engin Yayıncılık.

Çeviker, A. (2013). Ankara amatör süper lig futbolcularının antrenörlerinde gözlemledikleri etik ve etik dışı davranışlar. Yüksek Lisans Tezi, Gazi Üniversitesi, Ankara.

Dolaşır-Tuncel S., \& Büyüköztürk Ş. (2009). Antrenörlerin mesleki etik ilkeleri nelerdir? nasıl ölçülür? ölçek geliştirme: ölçeklerin geçerlik ve güvenirliği. Spormetre Beden Eğitimi Ve Spor Bilimleri Dergisi, 7(4), 159-168. https://doi.org/10.1501/Sporm_0000000166

Fain, G. (1992). Ethics in health, physical education, recreation and dance. Eric Clearinghouse On Teacher Education Washington, 1(4).

Genç, Z., Kazez, H., \& Fidan, A. (2013). Çevrimiçi etik dışı davranışlarının belirlenmesi için bir ölçek uyarlama çalışması. Akademik Bilişim 2013 - Xv. Akademik Bilişim Konferansı Bildirileri 23-25 Ocak 2013 - Akdeniz Üniversitesi, Antalya.

Gürpınar, B. (2009). Basketbol ve futbol hakemlerinin karşılaştıkları sportmenlik dışı davranışlar ve bu davranışların çeşitli değişkenler açısından incelenmesi. Doktora Tezi, Gazi Üniversitesi, Ankara.

Güven, Ö., \& Öncü, E. (2012). Antrenörlerin etik dışı davranışları ile ilgili sporcu algısı ölçeğinin geliştirilmesi. Spormetre Beden Eğitimi Ve Spor Bilimleri Dergisi, 10(2), 67-75. https://doi.org/10.1501/Sporm_0000000222.

Güvendi, B., Türksoy, A., Keskin, N., Altıncı, E. B., \& Şahin, S. (2016). Antrenörlerin mesleki etik ilkelere uyma düzeyleri ile kişilik özellikleri arasındaki ilişkinin incelenmesi. Uluslararası Hakemli Psikiyatri ve Psikoloji Araştırmaları Dergisi, 7, 43-61.

Janelle, K., \& Taylor, G. (1994). A code of ethics for physical education majör. Physical Educator, 51(3), 144-148.

Karakoç, Ö., Yüksek, S., Aydın, A.D., Karakoç, B., Yetiş, Ü., \& Baydil, B. (2011). Milli takım düzeyindeki erkek judocuların kulüp antrenörlerinde gözlemledikleri etik dışı davranışlar. Kastamonu Eğitim Dergisi, 19(1), 321-332.

Kıranlı, S. (2002). Ortaöğretim yöneticilerinin etik ilkelere uyma ve etik ikilemleri çözümleme yeterliliği. Doktora Tezi, Osmangazi Üniversitesi, Eskişehir.

Öncen, S., \& Aydın, S. (2019). A modelling of the effect of biomotor capabilities on the special ablitiy test course. World Journal of Education, 9(2), 103-108.

Özbek, Ö. (2003). Beden ĕgitimi öğretmenlerinin mesleki etik ilkeleri ve bu ilkelere uyma düzeyleri. Doktora Tezi Ankara Üniversitesi, Ankara.

Şimşek, Y., \& Altınkurt, Y. (2009). Okul müdürlerinin etik liderlik uygulamalarına ilişkin öğretmen görüşleri. I. Uluslararası Türkiye Eğitim Araştırmaları Kongresi. 1-3 Mayıs 2009 Çanakkale/Türkiye.

Togo, O. T. (2016). Secondary education students effects of personality structure in recreational sports activity. Marmara University Journal of Sport Science, 1(1), 75-84.

Yaman, E., Çetinkaya-Mermer, E., \& Mutlugil, S. (2009). İlköğretim okulu öğrencilerinin etik davranışlara ilişkin görüşleri: Nitel bir araştırma. Değerler Ĕ̈itimi Dergisi, 7(17), 93-108.

William, C., Davis, K., \& Post, E. J. (1988). Business and society, corporate strategy, publicly, Ethics. Usa: Mc. Graw Hill Publishing Company. 